\title{
Identifying the climatic conditions in Iraq by tracking down cooling events in the North Atlantic Ocean in the period 3000-0 BC
}

\begin{abstract}
North Atlantic Oscillation (NAO), monthly averages of precipitation in the Baghdad station, and petrologic tracer proxy data for ocean properties in the North Atlantic (NA) have been used in an attempt to identify climatic conditions in Iraq during the study period. The study showed that contemporary changes in precipitation in Iraq are associated with NAO, as a negative relationship is found between them. Moreover, the study found that there is a strong negative correlation between NAOI and SST in NA, where drift ice indices explain between $33-36 \%$ of the NAOI variability.

The prolonged of cold Holocene periods led to a radical oceanography and atmospheric changes in the NA and the Mediterranean Sea, effectively contributing to the prevalence of cold and drought in the EM, including Iraq.

The analysis revealed as many as four intervals of significant cool drought phases prevailing over Iraq during the periods 2650-2500, 2200$1900,1300-1200$ and 1000-850 BC
\end{abstract}

Keywords

Iraq • North Atlantic Oscillation • drift ice indices • drought intervals • Eastern Mediterranean

(c) University of Warsaw - Faculty of Geography and Regional Studies

Introduction

There is good evidence to document that the modern climate regime of the Eastern Mediterranean (EM), which is characterized by hot, dry summers and mild, wet winters, has remained constant since almost $3000 \mathrm{BC}$. Meanwhile, the southward shift of the boreal summer Inter-Tropical Convergence Zone (ITCZ) and the weakening of the monsoon system are associated with the return of summer precipitation to the regions where they occur nowadays. The weakening of the monsoon system related to solar activity reached a minimum after approaching the south coast of the Mediterranean (e.g. Thamban et al. 2007; El-Moslimany 1983; Roberts et al. 2011; Fleitmann et al. 2007). Because of the region's position between the subtropical highs and the northerly westerlies, the southward shift of the westerlies following the southern movement of the ITCZ facilitates the movement of depressions of Atlantic origin into the region. These results enhanced moisture transport and regionally reinforced cyclogenesis (Cullen et al. 2002). This means the Mediterranean and NA zones and their climate are strongly controlled by largescale atmospheric patterns.

Furthermore, the EM region, especially Mesopotamia, witnessed the rise and abrupt collapse of many agriculture-based civilizations, this cycle of societal rise and collapse repeating itself many times over several millennia. However, many studies have hypothesized that climate change affected societies in this region and even forced these civilizations to totally collapse (Weiss et al. 1993; Cullen et al. 2000b; Neuman \& Parpola 1987).

The aim of this paper is to identify the climatic conditions in Iraq, accompanied by North Atlantic cooling events, which prevailed during the period from 3000 to $0 \mathrm{BC}$. This aim achieves,

\author{
Khamis D. Muslih¹, \\ 'Department of Geography \\ College of Arts University of Baghdad \\ ${ }^{2}$ Faculty of Geography and Regional Studies \\ University of Warsaw \\ e-mail: khamies76@yahoo.com \\ Received: 31 May 2013 \\ Accepted: 25 March 2014
}

firstly, by studying the contemporary relationship between the North Atlantic Oscillation (NAO) during winter months (DJFM) and Iraqi precipitation represented by the Baghdad climate station ${ }^{1}$, secondly, by analyzing the relationship between the NAO and drift ice indices, including Hematite Stained Grains (HSG) and stack, which were derived from NA sediment cores by Bond et al. (2001). The HSG were measured in deep-sea sediment cores in the NA, as percentages of lithic grains (ice-rafted debris) in the $63-$ to $150-\mu \mathrm{m}$ size range. The stacked record was calculated by averaging of HSG percentage from MC52, V29-191, MC21, and GGC22 cores (Fig. 2). The findings will improve our understanding of the nature of atmospheric circulation patterns and anomalies of sea surface temperature (SST) associated with high and low NAO index in both EM and NA.

\section{Geographical setting and current climate}

Iraq is located in the South-West of Asia, in the Northeast of the Arab homeland. The area extends between $29^{\circ} 5^{\prime}$ to $37^{\circ} 22^{\prime} \mathrm{N}$ and $38^{\circ} 45^{\prime}$ to $48^{\circ} 45^{\prime} \mathrm{E}$, encompassing a geographical area of $435052 \mathrm{~km}^{2}$. It is bounded on the North by Turkey, on the East by Iran, on the West by Syria, Jordan and Saudi Arabia, on the South by Arab Gulf, Kuwait and Saudi Arabia (Republic of Iraq 2010 - 2011) (Fig. 1).

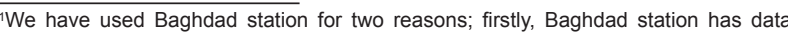
for the longest recorded period, started from 1889. Secondly, the Baghdad station is located on a flat area in central Iraq, in order to avoid local factors affecting the precipitation value, as is the case of the mountain area in northern Iraq.
} 


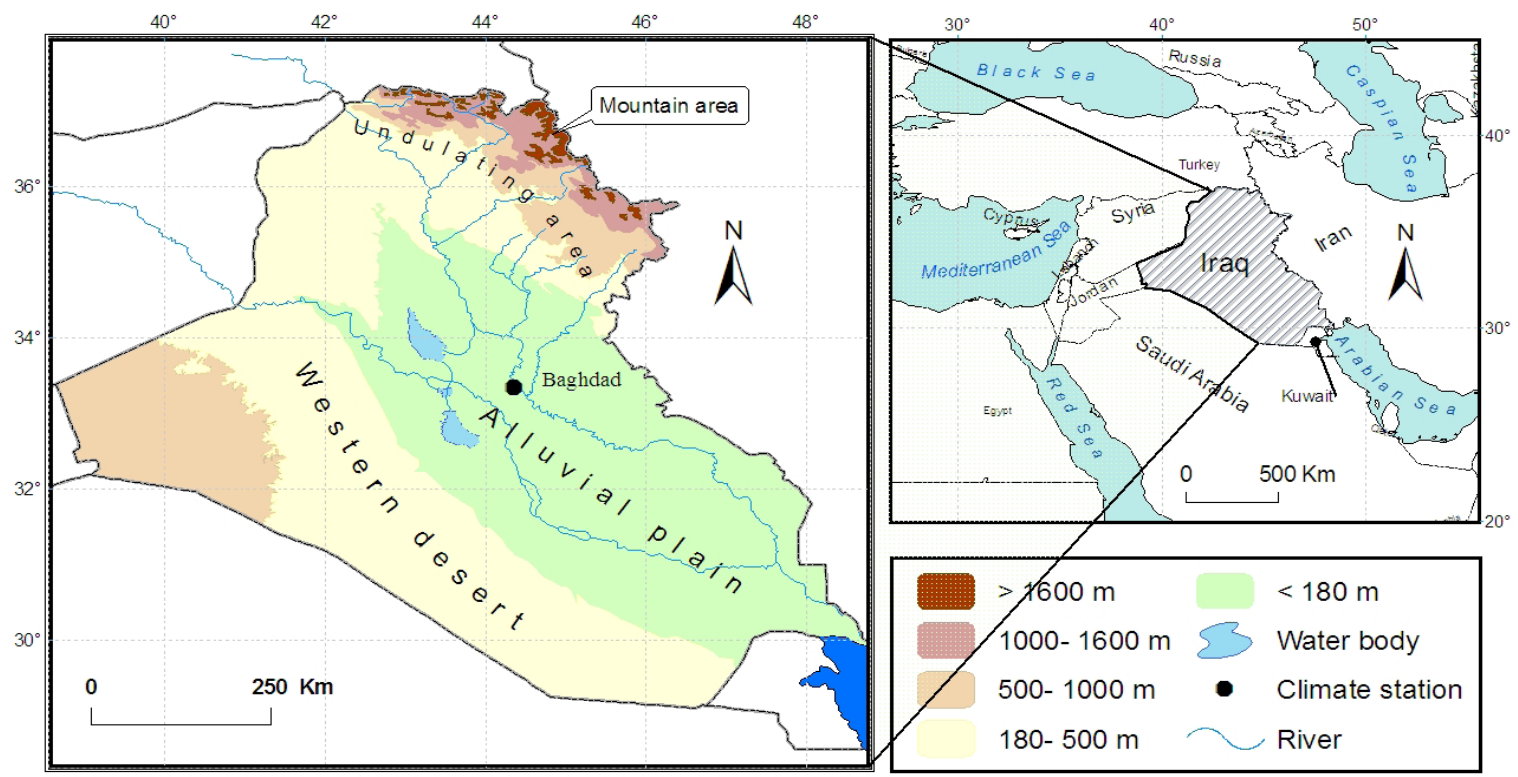

Figure 1. Regional and geographical setting of Iraq together with location of study area Source: satellite image of Iraq (DEM), resolution 30 m, year 2005

Topographically, Iraq is divided into four geographic zones (Fig. 1). The mountain areas of the north and northeast constitute $5 \%$ of the total Iraqi area. Undulating lands south of the first region cover $15 \%$ of the total area, alluvial plain along and between the lower courses of the Tigris and Euphrates from the center to southern Iraq, where the rivers empty into the Arabian Gulf with $20.5 \%$ of the total area. Finally, the rocky and sandy western desert covers $59.5 \%$ of the total area of Iraq (Susa 1963; Malinowski 2003).

The Iraqi climate has been strongly influenced by its geographical location, becoming continental and subtropical semi-arid in type. In summer, a strong Azores anticyclonic circulation predominates, while in winter this high-pressure system collapses and is replaced by periodic low pressure systems that move from west to east across Iraq, bringing winter rain in Iraq and snowfall in the mountain region of the north. From this point of view, the precipitation in Iraq and all EM is primarily of cyclonic origin (Kostopoulou \& Jones 2007).

These seasonal migrations of subtropical high pressure and mid-latitude low pressure allow the division of Iraq into three distinct climate regions according to the Köppen climate classification (Malinowski 2003); The Mediterranean climate regime (Csa) of the northern mountains, the Subtropical Steppe climate (BSh) of the upland region south of the first region, and Subtropical Desert (BWh) in the central and southern Iraqi area.

Generally, the climate of Iraq is characterized by hot dry summers, when mean maximum temperature is likely to reach over $48^{\circ} \mathrm{C}$ in the hottest months, especially in the center and south of the country. The winter is cool to cold, the mean minimum temperature dropping to near freezing in the north and as low as to $5^{\circ} \mathrm{C}$ in the south. The annual rainfall in the northern mountains reaches $1000 \mathrm{~mm}$, falling to less than $100 \mathrm{~mm}$ in the south and southwest. $90 \%$ of the annual rainfalls occur between November and April (Iraqi Meteorological Organization and Seismology). The higher rainfall in the north is due to the high number of low-pressure system advections from the Mediterranean Sea (between 75-100 cyclones a year) across this region and the rise over the mountains (Walker 2005).
Material and Methods

To achieve our goal, we present records of NAOI, obtained from: a) The normalized winter sea level pressure (SLP) difference between Lisbon (Portugal) and Stykkisholmur (Iceland) extending from 1889 to 2009 (The Climate Data Guide). b) Winter NAO reconstruction for the years 1049-1889 and decadal scale variations in a speleothem-based precipitation proxy from Scotland and a tree-ring based drought proxy from Morocco (Fig. 2) (Trouet et al. 2009). The monthly precipitation data for Baghdad station from 1889 to 2010 were also used. Furthermore, the paper focuses on North Atlantic sediment cores used for drift ice indices, including Hematite Stained Grains (HSG) and stack from MC52, VM29-191, MC21, and GGC22 cores (Fig. 2) (Bond et al. 2001; 2008).

Simple regression and linear correlation were applied to identify statistical relationships between the two sets of variables mentioned above; firstly, between the NAOI and monthly average of precipitation for Baghdad stations and secondly, between the ice drift indices recorder for the NA and winter NAOI reconstruction record for the period 1049-2000. This was done in order to deeper understanding of the nature of the relationship between the NAOI and SST in the North Atlantic Ocean and the Mediterranean Sea. Finally, we use these relationships to identify the climatic conditions for the study period.

\section{Results and Discussion}

Short-term observations present the relationship between the NAO and precipitation

The North Atlantic Oscillation (NAO) is the dominant mode of interannual-decadal atmospheric variability for the Atlantic sector, accounting for 20 to $60 \%$ (from December to March - DJFM) temperature and precipitation variability in Northern Hemisphere including the EM region over the last 150 years (Hurrell 1995). The regression line (Fig. $3 \mathrm{~A})$ suggests a negative correlation $(r=-0.16)$ between the winter NAOI and precipitation at the Baghdad station, significant at probability level $90 \%$. Whereas the high NAO index is accompanied by a decrease in precipitation in Iraq, enhanced precipitation in Iraq usually relates to a low NAOI (Fig. 3 A and B). 


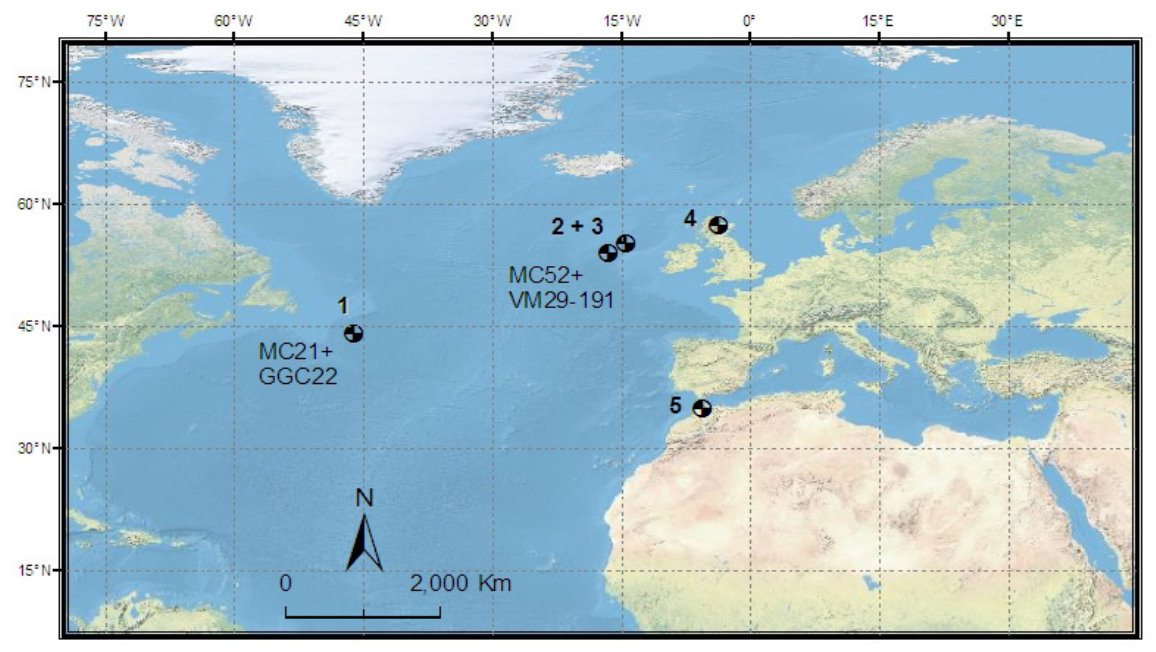

Figure 2. Location of sites discussed in the text: $(1+2+3)$ North Atlantic sediment cores used for ice drift indices record (after Bond et al. 2001; 2008); $(4+5)$ Cores used for NAO reconstruction; Speleothem-based precipitation proxy from Scotland and tree-ring drought proxy from Morocco respectively (after Trouet et al. 2009)
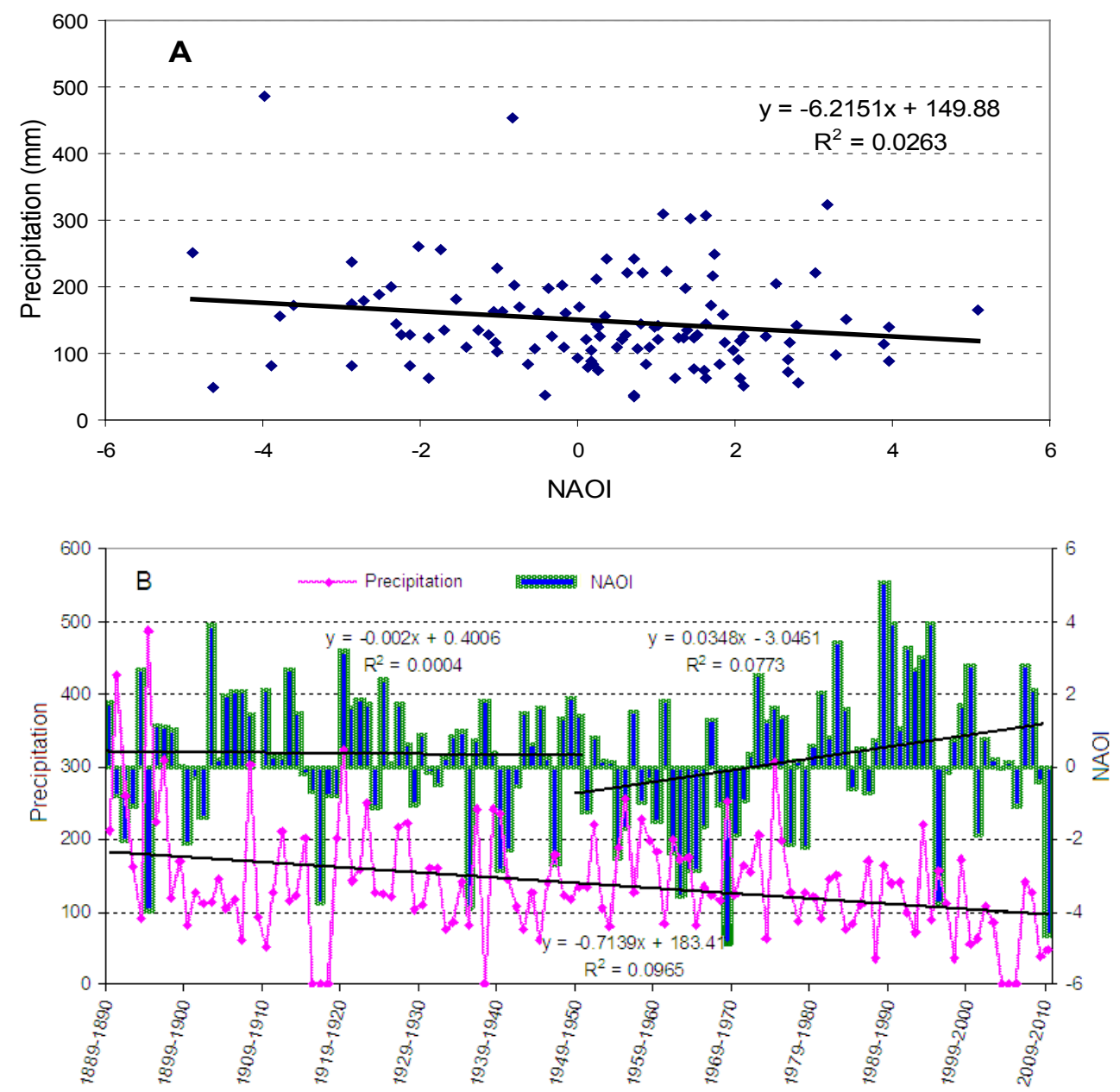

Figure 3. Correlation between the NAOI and precipitation at the Baghdad station (A), and multiannual changes in NAOI and Iraqi precipitation (B). Note. The unpublished data from Iraqi Meteorological Organization and Seismology 


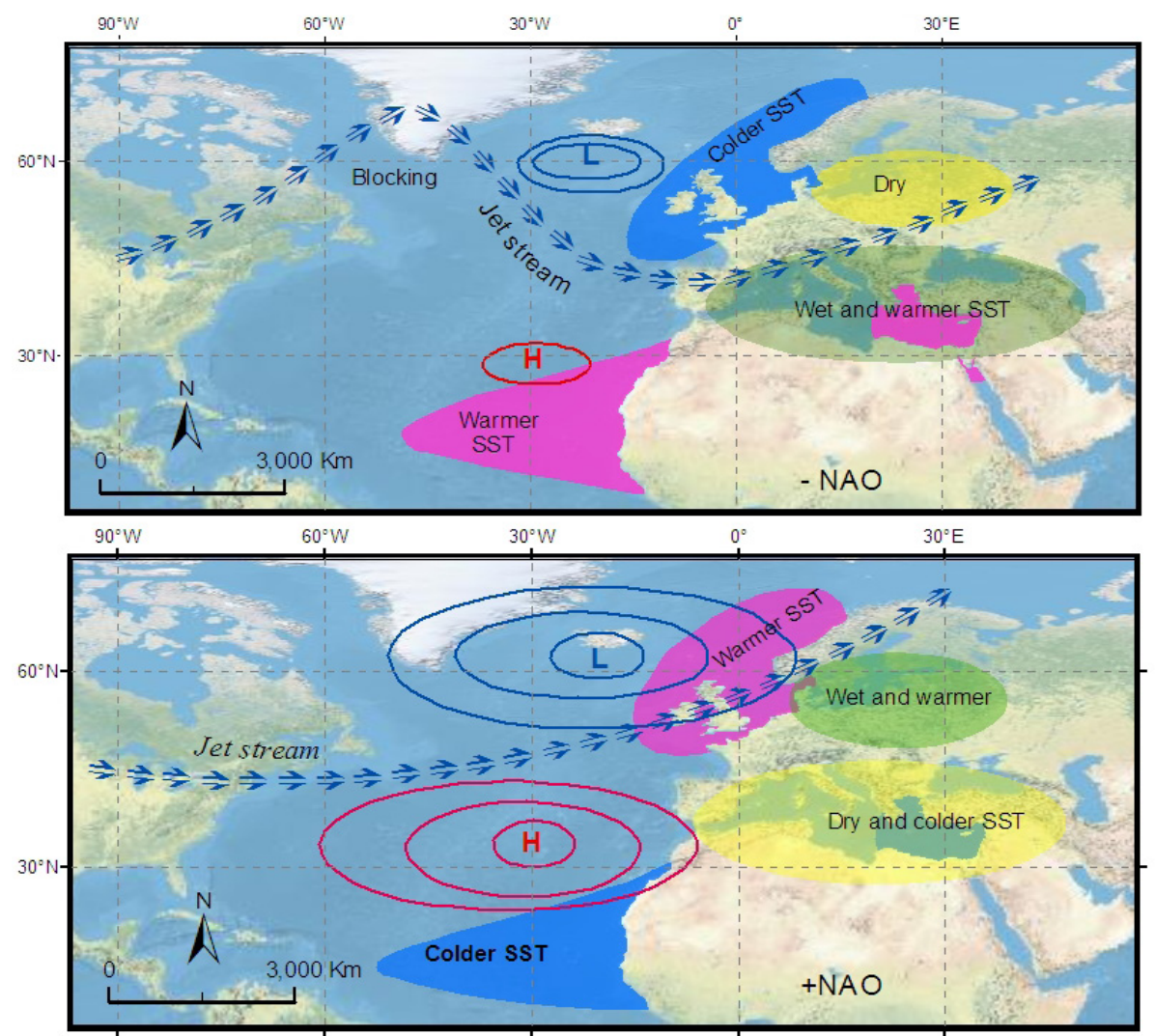

Figure 4. The contemporary regional SST anomalies and atmospheric circulation associated with the negative and positive AO/NAO index Note. The data are from, (Rimbu et al. 2003; Hurrell 1995; Hurrell and Deser 2009)
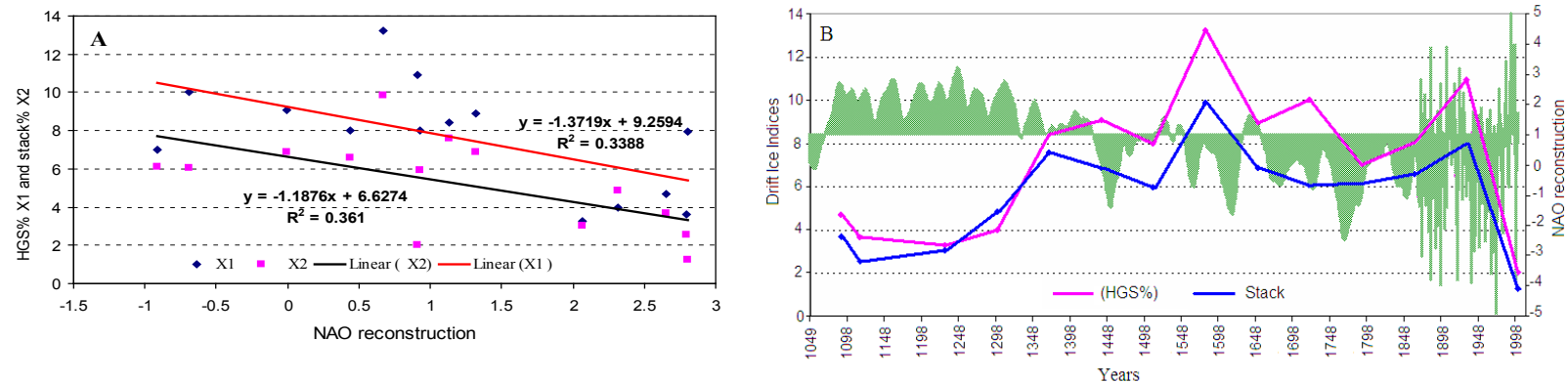

Figure 5. Regression between the NAOI reconstruction and drift ice indices (A), and time series correlation between the NAOI reconstruction and drift ice indices $(B)$

Note. The data are from, (Bond et al. 2001, 2008; Trouet et al. 2009)

The low value of $(r)$ here perhaps is due to the distance from the genesis of cyclones centering over the Atlantic Ocean and the Mediterranean Sea, as well as the location of Iraq in the southern rim of these cyclones impacts, which is reflected in the decrease in precipitation and its highly variable pattern.

The linear trend (Fig. 3B) also shows a clear negative relationship between the time series and precipitation where precipitation decreases over time at the Baghdad station. On the other hand, the study shows a positive correlation between the time series and NAOI, especially after the middle of the last century since the values of NAOI are rising (Fig. 3).

The correlations mentioned above support the previous studies that investigated the link between EM region climate and the NAOI. These studies pointed to the far-field influence of the NAO on the Middle East climate, and clarify the distinct dipole relationship with the subtropical - subpolar NAO pressure gradient (e.g. Cullen et al. 2000a, 2002).

In the high NAOI phase, the Icelandic Low and the Azores High were well developed, with pressure anomalous cores lower and higher than normal, respectively. This pressure disposition leads to strong pressure gradients and strengthens westerly winds across the NA accompanied by a more northern jet axis. They cause a relatively mild and humid winter over northern Europe. Additionally, the anomalously high pressure system covers large parts of the Mediterranean and Middle East regions, resulting in northerly winds in the eastern part that drive the 
advection of dry and cold air (Fig. 4). During the low NAOI, the westerly winds are weaker than normally across the NA and northern Europe, with the axis of the westerlies clearly zonal and lying further south associated with a southward shift of the jet stream. This synoptic condition led to a relatively humid phase in the southern Europe and in the Mediterranean region and relatively arid phase in northern and central Europe (Wanner et al. 2001; Hurrell 1995; Hurrell \& Deser 2009).

Millennium relationships between the Drift Ice Indices and NAO

Many studies (e.g. Visbeck et al. 1998, 2003; Rimbu et al. 2003) examining the relationship between the SST and NAOI have found a strong response between the two. Thus, the observed relationship between NAOI and SST supports the theory of the strong and immediate response of the ocean surface. On multidecadal or longer time scales, changes in the ocean heat storage and heat transport have an increasingly important impact on the climate (Visbeck et al. 2003). The relationships between the drift ice indices (Hematie Stained Grains (HGS) and stack) and NAOI suggests a strong negative correlation ( $r=-0.58$ for HGS and $r=-0.60$ for stack) with NAO, significant at probability level $95 \%$ (Fig. 5A).

The correlation between the ice drift indices in NA and NAO supports the strong response of NAO to SST. While the SST in NA is low, the NAO is in a negative phase (Fig. 5B). Increased drift ice indices associated with cooler surface water temperatures south of Greenland takes place during phases of cold atmosphere recorded in Europe, Greenland, and the subtropical north Atlantic (Bond et al. 2001). Generally the long-term cooling in the NA can be explained by decreasing solar activity, which led to the weakness of the Icelandic low (Rimbu et al. 2003) associated with intensified high-pressure anomaly over Greenland, producing abnormally strong northerly winds that spread the Nordic Sea ice drift southward into the sub-polar NA (Lohmann et al. 2005; Bond et al. 2001).

These cooling periods and response of the ice drift in NA were associated with positive SST trends at the EM (Fig. 4). Moreover, the cooling phases in NA induced a southward shift of the northern hemisphere polar front, which accompanied by strengthening of the westerly jet, displaced it towards the Mediterranean region (Fig. 4) (Lamy et al. 2006; Hurrell \& Deser 2009). These atmospheric conditions over mid-latitude led to the frequent and more intense cyclones which were normally fed by moisture uptake from the relatively warm Mediterranean surface waters, supplying moisture towards the eastern Mediterranean region including Iraq (Kostopoulou \& Jones 2007).

Extrapolation of short-term observation for the assessment of climatic conditions linkage with North Atlantic cooling

Recent studies on Holocene millennial-scale climate changes, which were carried out in the Mediterranean Sea have shown that the eastern Mediterranean region was very sensitive to climatic and oceanographic changes in the NA (e.g. Rimbu et al. 2003, 2004; Lamy et al. 2006; Kim et al. 2007). Here we try to identify the types of climate that prevailed during the period 3000-0 $\mathrm{BC}$ by considering ice drift record from the NA (Fig. 2) (Bond et al. $2001 ; 2008)$ based on the analysis mentioned above. The main observations outlined above are the relationships between NAOI and precipitation in Iraq, and the correlation of NAO with drift ice indices in the NA in order to determine the SST associated with high and low index values in both the NA and EM. The short-term observation indicates that less (more) ice drift represents warmer (cooler) sea surface temperatures, and a positive (negative) NAOI represents less (more) precipitation on Iraq (Fig. 3 and 5 , and above discussion). Our findings confirm the research of Rimbu et al. (2003), who suggested that the cooling trend is part of a regional SST pattern that resembles a contemporary SST pattern, which is related to the NAOI. This suggests a possible role of NAO in generating the Holocene SST variability, the negative SST anomalies in the northeast Atlantic region together with positive SST anomalies in the EM. From Fig. 6, we note that during the period $3000-0 \mathrm{BC}$ there are at least four abrupt instances of ocean surface cooling characterized by the ice drift index event in the NA, with peaks around 2650-2500, 22001900, 1300-1200 and 1000-850 BC.

According to the previous arguments, the similarity between these cooling phases and the SST trend associated with negative NAOI led to the southward movement of the polar front. The existence of a polar front caused an enhancement of the strength and frequency of storms that are activated by moisture being absorbing from the relatively warmer Mediterranean surface water, which led to an increase in precipitation in Iraq, meaning the four intervals mentioned above were wet phases. However, our findings seems to be contradicted by many studies covering Mesopotamia (e.g. Cullen et al. 2000b; Neuman \& Parpola 1987; Weiss et al. 1993), which have indicated that none of

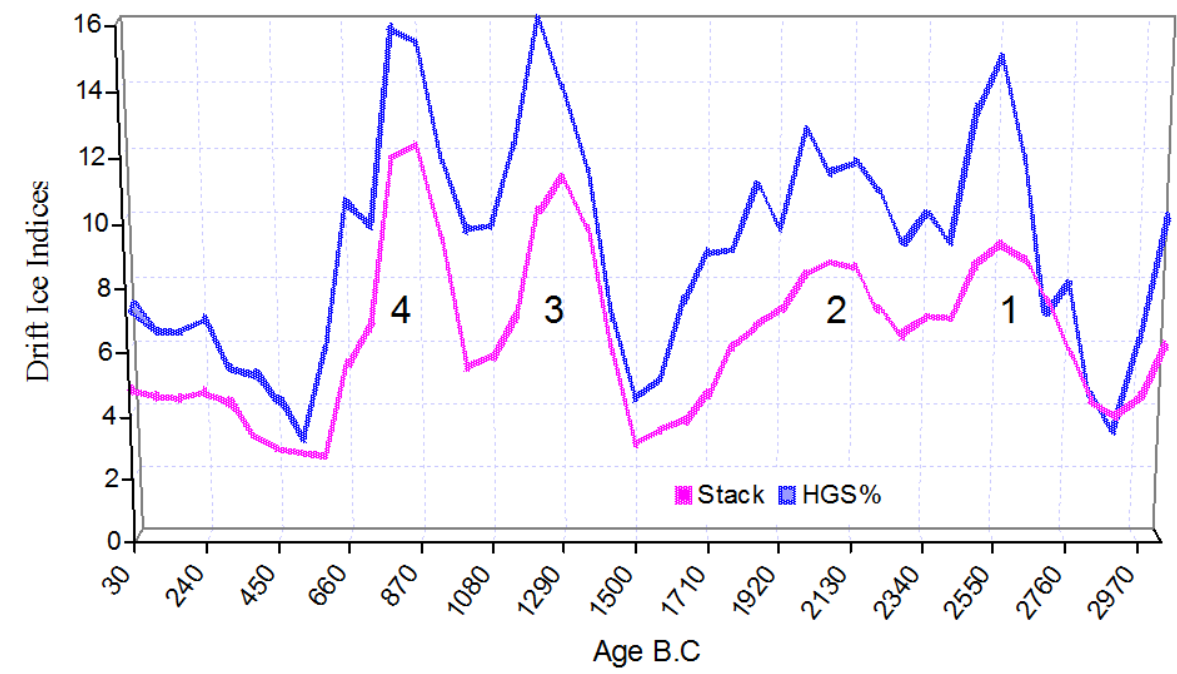

Figure 6. Drift ice indices (Stack of four ice drift records from MC52, VM29-191, MC21 and GGC22 cores and drift ice for the MC52 and VM29-191 core) in NA (Fig. 2) during the period 3000-0 BC

Note. The data are from, (Bond et al. 2001; 2008) 
these periods were coded as humid periods. However, Cullen et al. (2000b) suggested an increase of eolian dolomite and calcite at the bottom of the Gulf of Oman, which was transported by the wind from Mesopotamia in the period $2025 \pm 150 \mathrm{BC}$, and lasted nearly 300 years, meaning a prevalence of drought during this period. The findings of Cullen et al. confirmed the study of Weiss et al. (1993), which suggested the above mentioned period was a dry period in Mesopotamia accompanied by largescale abandonment of settlements in northern Mesopotamia as a result of arid farmers. Moreover, Neuman and Parpola (1987) found that the period 1200-900 BC was a severe period of drought resulting in political and social instability.

This contradiction encouraged the researcher to look for potential effects associated with Holocene cooling events on the atmospheric and thermohaline circulations between the NA and the Mediterranean Sea; we find that the ideal model discussed above was prevailing during the normal situation - this holds for the present time, but not during exceptionally Holocene cooling events, as potential feedback resulting from changes in thermohaline circulation prevent the application of such an ideal model. On a millennial scale, period of orbitally induced declines of solar irradiance in the NA might have stimulated large ice sheet collapses and ice-rafted debris discharges (Bond et al. 2001). The prolonged periods of cooling are associated with ice-rafted debris, altering the rate of deep-water formation in the north Atlantic (NADW) (Keigwin \& Boyle 2000; Nieto-Moreno et al. 2011). Thus, reduced NADW rate and weakening global thermohaline circulation may allow these cold pole waters to spread into Mediterranean Sea. This cold water would have reduced the atmosphere-sea surface thermal gradient, which led to a dramatic reduction in the strength and the frequency of storms, which normally benefit from the uptake of moisture from the relatively warmer Mediterranean surface water. In return, the decrease in the number and intensity of storms consequently lead to a significant decrease in precipitation over the EM region (Bartov et al. 2003). Bartov et al. (2003) and Kwiecien et al. (2009), who link drought intervals in the EM region with Heinrich events and the last glacial period respectively, have floated similar scenarios.

According to the aforementioned proposal, there is a relationship between the long-term cooling periods in the NA and the changes of the NADW that resulted from the flow of cold water toward the Mediterranean Sea. This cold water led to a reduction in the atmosphere-sea surface thermal gradient, hence a decrease in the frequency and severity of storms and attendant drought in the EM region, including Iraq. However, we suggest that the four intervals identified in (Fig. 6) were cold, dry intervals:

- The first interval was between 2650 and 2500 BC.

- The period between 2200 and 1900 BC witnessed the second cold dry interval; the drought occurring in this period was on a global scale, documented by several studies at mid and lower latitudes, especially across the EM region. These studies pointed to the drought climate in Mesopotamia (e.g. Cullen et al. 2000b; Weiss et al. 1993). The same period has also been observed over a widespread area besides the Mesopotamian region including; The Indus valley in the Makran (Possehl 1997), the weakening of the monsoon in southern Asia (Hong et al. 2003), and coinciding with cool, dry conditions over several areas in the northern Hemisphere (Mayewski et al. 2004).

- The period 1300-850 BC pointed to the two peak cooling phases (1300-1200 and 1000-850 BC) separated by a warm period lasted about two centuries. These were cool dry intervals, according to previous interpretations, these cold dry conditions having been described by many proxy records from the EM including Iraq (Neuman \& Parpola 1987; Kaniewski et al. 2010) and widespread area around the world (Mayewski et al. 2004).

\section{Conclusions}

The aim of the present study is to identify the climate conditions in Iraq during the period 3000-0 BC, depending on ocean sediment properties of the NA. To achieve our goal, we compare the modern relationship between winter NAOI and Iraqi precipitation and compare the NAOI with the content of drift ice indices that derived from the NA, in order to improve our understanding of the nature of atmospheric circulation patterns and SST anomalies associated with high and low NAOI in both, the EM and NA.

The most important conclusions drawn from the compilation and analysis of proxy records are:

1. During the contemporary period, a negative relationship appeared between the NAOI and precipitation in Iraq represented by the Baghdad station. This negative relationship strengthened the tests of the relationship between time series, precipitation and $\mathrm{NAO}$, as the linear trend showed the decrease of precipitation in Iraq over time. In return, the linear trend indicates an increase of NAO values over time, especially in the following the middle of the last century.

2. Regression analysis also showed a strong negative correlation between the NAOI and drift ice indices, namely that the cooler SST in the NA meaning a negative NAOI led to an increase in precipitation in Iraq and vice versa.

3. Potential feedbacks associated with extreme cooling intervals played an important role in the formulation of the nature of the climate characteristics during Holocene period. The prolonged of these periods in the NA leads to spread of cold polar water into the Mediterranean Sea, which then led to a reduction in the strength and the frequency of storms, and hence less precipitation in the EM region, including Iraq.

Consequently, four intervals of cold, dry climate appeared during the study period, which correspond with periods of severe cooling in the NA $(2650-2500 ; 2200-1900 ; 1300-1200 ; 1000$ $800 \mathrm{BC})$.

\section{Acknowledgments}

This paper is a part of my PhD dissertation under the guidance of Prof. dr hab. Krzysztof Błażejczyk. Therefore, I would like to thank him for his valuable insights.

\section{References}

Bartov, Y, Goldstein, S, Stein, M \& Enzel, Y 2003, 'Catastrophic arid episodes in the Eastern Mediterranean linked with the North Atlantic Heinrich events', Geology, vol. 31, no. 5, pp. 439-442.

Bond, G, Kromer, B, Beer, J, Muscheler, R, Evans, MN, Showers, W, Hoffmann, S, Lotti-Bond, R, Hajdas, I \& Bonani, G 2001, 'Persistent solar influence on north Atlantic climate during the Holocene', Science, vol. 294, pp. 2130-2136.

Bond, G, Kromer, B, Beer, J, Muscheler, R, Evans, MN, Showers, W,
Hoffmann, S, Lotti-Bond, R, Hajdas, I \& Bonani, G 2008, North Atlantic Holocene Drift Ice Proxy Data. IGBP PAGES/ World Data Center for Paleoclimatology Data Contribution Series 2008-018. NOAA/NCDC Paleoclimatology Program, Boulder CO, USA. Available from: ftp://ftp.ncdc.noaa.gov/pub/\%20 data/paleo/contributions_by_author/bond2001/bond2001. txt"ftp://ftp.ncdc.noaa.gov/pub/data/paleo/contributions_by_ author/bond2001/bond2001.txt>. [22 November 2012]. 
Cullen, HM \& deMenocal, P 2000a, 'North Atlantic Influence on Tigris-Euphrates Streamflow', International journal of climatology, vol. 20, pp. 853-863.

Cullen, HM, deMenocal, PB, Hemming, S, Hemming, G, Brown, FH, Guilderson, T \& Sirocko, F 2000b, 'Climate change and the collapse of the Akkadian empire: evidence from the deep sea', Geology, vol. 28, pp. 379-382.

Cullen, H, Kaplan, A, Arkin, PA \& Demenocal, P 2002, 'Impact of the north Atlantic oscillation on Middle Eastern climate and stream flow', Climatic Change, vol. 55, pp. 315-338.

El-Moslimany, AP 1983, History of climate and vegetation in the eastern Mediterranean and the Middle East from the Pleniglacial to the Mid-Holocene, Ph.D Thesis, University of Washington.

Fleitmann, D, Burns, SJ, Mangini, A, Mudesee, M, Kramers, J, Villa, L, Neff, U, Al-Subbary, AA, Buettner, A, Hippler, D \& Matter, A 2007, 'Holocene ITCZ and Indian monsoon dynamics recorded in stalagmites from Oman and Yemen (Socotra)', Quaternary Science Reviews, vol. 26, pp. 170-188.

Hong, YT, Hong, B, Lin, QH, Zhu, YX, Shibata, Y, Hirota, M, Uchida, M, Leng. X, Jiang, H, Xu, H, Wang, H \& Yi, L 2003, 'Correlation between Indian Ocean summer monsoon and North Atlantic climate during the Holocene', Earth and Planetary Science Letters, vol. 211, pp. 371-380.

Hurrell, JW 1995, 'Decadal trends in the North Atlantic Oscillation: Regional Temperatures and Precipitation', Science, vol. 269, pp. 676-679.

Hurrell, JW \& Deser, C 2009, 'North Atlantic climate variability: The role of the North Atlantic Oscillation', Journal of Marine Systems, vol. 78, pp. 28-41.

Iraqi Meteorological Organization and Seismology, Department of climate, monthly precipitation and temperature data. (Unpublished data)

Kaniewski, D, Paulissen, E, Van Campo, E, Weiss, H, Otto, T, Bretschneider, J \& Van lerberghe, K 2010, 'Late second-early first millennium BC abrupt climate changes in coastal Syria and their possible significance for the history of the Eastern Mediterranean', Quaternary Research, vol. 74, pp. 207-215.

Keigwin, LD \& Boyle, EA 2000, 'Detecting Holocene changes in thermohaline circulation', proceedings of the National Academy of Science, vol. 97, pp. 1343-1346.

Kim, J, Meggers, H, Rimbu, N, Lohmann, G, Freudenthal, T, Muller, PJ \& Schneider, RR 2007, 'Impacts of the North Atlantic gyre circulation on Holocene climate off northwest Africa', Geology, vol. 35, no. 5, pp. 387-390.

Kostopoulou, E \& Jones, PD 2007, 'Comprehensive analysis of the climate variability in the eastern Mediterranean. Part II: relationships between atmospheric circulation patterns and surface climatic elements', International Journal of Climatology, vol. 27, pp. 1351-1371.

Kwiecien, O, Arz, HW, Lamy, F, Plessen, B, Bahr, A \& Haug, G 2009, 'North Atlantic control on precipitation pattern in the eastern Mediterranean / Black Sea region during the last glacial', Quaternary Research, vol. 71, pp. 375-384.

Lamy, F, Arz, HW, Bond, GC, Bahr, A \& Patzold, J 2006, 'Multicentennial-scale hydrological changes in the Black Sea and northern Red Sea during the Holocene and the Arctic/North Atlantic Oscillation', Paleoceanography, vol. 21, PA10008, pp. 1-11. Availble from: WILEY [21 February 2006].

Lohmann, G, Lorenz, SJ \& Prange, M 2005, 'Northern highlatitude climate changes during the Holocene as simulated by circulation models', Geophysical Monograph, vol. 158, pp. 273-288.

Malinowski, JC (ed) 2003, Iraq; A Geography, West Point, NY: United States Military Academy.

Mayewski, PA, Rohling, E, Stager, JC, Karlén, W, Maasch, KA, Meeker, LD, Meyerson, EA, Gasse, F, Van Kreveld, S, Holmgren, K, Lee-Thorp, J, Rosqvist, G, Rack, F,
Staubwasser, M, Schneider, RR \& Steig, EJ 2004, 'Holocene climate variability', Quaternary Research, vol. 62, pp. 243255.

Neumann, J \& Parpola, S 1987, 'Climate change and the eleventhtenth century eclipse of Assyria and Babylonian', Journal of Near Eastern Studies, vol. 46, no. 3, pp. 161-182.

Nieto-Moreno, V, Martinez-Ruiz, F, Giralt, S, Jiménez-Espejo, F, Gallego-Torres, D, Rodrigo-Gámiz, M, García-Orellana, J, Ortega-Huertas, M and de Lange, GJ 2011, 'Tracking climate variability in the western Mediterranean during the Late Holocene: a multiproxy approach', Climate of the past, vol. 7, pp. 1395-1414. Available from: <http://www.climpast.net/7/1395/2011/html> [21 February 2011].

Possehl, G 1997, 'Climate and the eclipse of the ancient cities of the Indus'. In Third Millennium BC. Climate change and old world collapse, ed. H. Dalfes, G, Kukla, \& H, Weiss, Heidelberg; Springer-Verlag, pp. 193-244.

Republic of Iraq, Ministry of Planning, Control statically organization "Annual statistical abstract", part one, pp. 2010-2011.

Rimbu, N, Lohmann, G, Kim, JH, Arz, HW \& Schneider, R 2003, 'Arctic/North Atlantic Oscillation signature in Holocene sea surface temperature trends as obtained from alkenone data', Geophysical research letters, vol. 30, no 6, pp. 1-13.

Rimbu, N, Lohmann, G, Lorenz, SJ, Kim, JH \& Schneider, RR 2004, 'Holocene climate variability as derived from alkenone sea surface temperature and coupled ocean-atmosphere model experiments', Climate Dynamics, vol. 23, pp. 215-227.

Roberts, N, Brayshaw, D, Kuzucuoglu, C, Perez, R \& Sadori, $L$ 2011, 'The mid-Holocene climatic transition in the Mediterranean: Causes and consequences', The Holocene, vol. 21, no. 1, pp. 3-13.

Susa, A 1963, Baghdad's flooding in history, the first section, Baghdad. (In Arabic)

The Climate Data Guide: Hurrell North Atlantic Oscillation (NAO) Index (station-based)." Available from: <http:// climatedataguide.ucar.edu/climate-data/hurrell-northatlantic-oscillation-nao-index-station-based>.

Thamban, M, Kawahata, H \& Rao, VP 2007, 'Indian summer Monsoon Variability during the Holocene as Recorded in Sediments of the Arabian Sea: Timing and Implications', Journal of Oceanography, vol. 63, pp. 1009-1020.

Trouet, V, Esper, J, Graham, N, Baker, A, Scourse, J \& Frank, D 2009, 'Persistent positive North Atlantic oscillation mode dominated the Medieval Climate Anomaly'. Science, vol. 324, pp. 78-80. Available from: <ftp://ftp.ncdc.noaa.gov/ $\mathrm{pub} / \mathrm{data} / \mathrm{paleo} /$ treering/reconstructions/nao-trouet2009. txt>. [22 November 2012].

Visbeck, M, Chassignet, EP, Curry, R, Delworth, T, Dickson, B \& Krahmann, G 2003, 'The ocean's response to North Atlantic Oscillation variability, in The North Atlantic Oscillation: Climatic Significance and Environmental Impact', eds JW Hurrell, Y Kushnir, G Ottersen, Geophysical Monograph Series, Washington, vol. 134, pp. 113-145.

Visbeck, M, Cullen, H, Krahmann, G \& Naik, N 1998, 'An oceans model's response to North Atlantic Oscillation like wind forcing', Geophysical research letters, vol. 25, no 24, pp. $4521-4524$.

Walker, M 2005, Iraq a Full-Year Study Climatology Study, Air Force Combat Climatology Center (AFCCC), Asheville, north Carolina.

Wanner, H, Bronnimann, S, Casty, C, Gyalistras, D, Luterbacher, J, Schmutz, C, Stephenson, DB \& Xoplaki, E 2001, 'North Atlantic Oscillation- concepts and studies', Surveys in Geophysics, vol. 22, pp. 321-382.

Weiss, H, Courty, MA, Wetterstrom, W, Guichard, F, Senior, L, Meadow, R \& Curnow, A 1993, 'The genesis and collapse of third millennium north Mesopotamian civilization', Science, vol. 261, pp. 995-1004. 